\title{
Editorial v. 29, n. 1 (2017)
}

A escrita deste editorial encontra-se inundada de afetos diversos. Este número de nossa Revista sai um dia depois de uma greve geral e nas vésperas do Dia do Trabalho, comemorado em nosso país este ano sem muitos motivos para tanto. A ambiguidade de afetos se dá justamente no confronto das lutas e retrocessos, na tensão de um passado a ser lembrado e de um futuro a ser forjado a duras penas. Nosso trabalho encontra-se neste momento delicado e emerge como forma de resistência. Não podemos nos privar de escrever, de pensar, de gerar conhecimento. Na leitura deste nosso número, espero que a força deste conhecimento que resiste, que incomoda e desacomoda esteja presente, pois é deste material que são feitas nossas lutas e conquistas. Quero ainda frisar que nosso trabalho se sustenta a partir de parcerias e, sem elas, não conseguimos viver. Queria abrir um pouco as redes que nos compõem para mostrar que a cada número precisamos de muitos, muitos parceiros. Em primeiro lugar, gostaria de agradecer aos autores que esperam pacientemente pelo momento da publicação. Sei do trabalho árduo que é publicar no Brasil e quantas são as exigências de produção em nosso campo. Agradeço também aos pareceristas que se dispõem a ler o texto de colegas, a doar seu tempo, tantas vezes exíguo para compor a parceria de escrita de nossos autores. Sem este trabalho não seria possível a publicação de nenhum artigo. Agradeço à parceria de antigos editores, como Márcia Moraes e Marcelo Santana, que fizeram esta revista caminhar durante muitos anos. Agradeço à parceria direta de Maria Lívia Nascimento e Cristine Mattar na manutenção deste nosso trabalho. Agradeço aos editores associados: Márcia Moraes, Paulo Vidal, Paula Curi, Claudia Osório, Danichi Misogushi, Adriana Rosa, que nos ajudam na avaliação prévia dos artigos a serem publicados. Agradeço ao Programa de Pós-Graduação de Psicologia da UFF por tantos e constantes esforços em manter nossa revista funcionando, nossa antiga coordenadora, Claudia Osório e nossa atual coordenadora Luiza Oliveira. Agradeço ao diretor de nosso Instituto de Psicologia, o professor Francisco Palharini pelos muitos esforços e grande parceria na manutenção de nossa Revista. Sem ela seria impossível manter nossas publicações. Agradeço à Pró-Reitoria de Pesquisa, Pós-graduação e Inovação (PROPPi) pelo auxílio que tem nos dado e à Superintendência de Tecnologia da Informação (STI) pelas muitas e repetidas tentativas de resolver problemas sempre recorrentes em nossa plataforma - o que nos prejudicou muito no ano passado. E gostaria de dar um agradecimento especial ao nosso suporte técnico, que responde pelo nome de Sergio Sant'Ana, incansável na busca de solução de problemas, na ajuda para que nossa revista esteja disponível e em todo o suporte que tem nos dado por tantos anos e de maneira sempre solícita e eficiente. Não poderia, nem gostaria que este trabalho permanecesse invisível porque a revista se faz com todos estes que a compõem.

Neste primeiro número de 2017 temos trabalhos inspiradores e potentes, como o artigo "Práticas de esporte, lazer e cultura do UNICEF", que nos convida a problematizar as práticas do Fundo das Nações Unidas para a Infância (UNI$\mathrm{CEF}$ ), em especial, as dirigidas às crianças e adolescentes pobres por meio de atividades de esportes, lazer e cultura como maneira de forjar segurança, saúde e prevenir situações de violência. Em "Saúde do trabalhador e economia solidária: estudo de uma cooperativa de construção civil" os autores discutem o potencial da Economia Solidária para o campo da saúde do trabalhador, em seguida, no artigo "Violência urbana e saúde mental: desafios de uma nova agenda?" os autores pensam como o fenômeno da violência produz impactos importantes para o setor saúde, seja como fator de agravo à população, ou como barreira de acesso aos serviços.

Em seguida, temos o artigo: "Cuidado em saúde no território na interface entre Saúde Mental e Estratégia de da Saúde Família" em que as autoras refletem sobre a complexidade do cuidado em saúde no território na intercessão entre a Saúde Mental e a Atenção Básica. Temos ainda o artigo: "Exame criminológico e psicologia: crise e manutenção da disciplina carcerária" em que os autores colocam em análise as estratégias de saber e os exercícios de poder que mantêm os exames criminológicos e a lógica criminalizante presente nos procedimentos carcerários, promovendo questionamentos à Psicologia, aos princípios presentes em seu código de ética e ao compromisso social da profissão. Temos ainda o artigo: "Cartografia nas pesquisas científicas: uma revisão integrativa" em que as autoras propõem analisar o uso da cartografia como método de pesquisa. Apresentamos também o artigo: "Dinâmicas profissionais contemporâneas: algumas contribuições da sociologia de Richard Sennett" em que as autoras propõem um diálogo entre a sociologia desse pensador e relatos de jovens profissionais sobre suas dinâmicas de trabalho.

Na continuação deste número temos o artigo: "A perversão enquanto estrutura e sua incidência na transferência" em que o autor aborda o conceito de estrutura perversa a partir das elaborações de Freud e Lacan. No artigo "Travestis brasileiras e escola: problematizações sobre processos temporais em gêneros, sexualidades e corporalidades nômades" os autores têm como propósito problematizar os processos de subjetivação relacionados às travestilidades, atravessados pelas novas configurações das expressões de gêneros, sexualidades e corporalidades, em tempos contemporâneos. Por fim, mas não menos importante, temos o artigo: "As artes adivinhatórias e a psiquiatria do futuro" em que os autores pensam a psiquiatria como "arte adivinhatória ou divinatória" engajada na previsão do futuro e pretendem assinalar o projeto biopolítico de gerenciamento da vida atrelado à psiquiatria contemporânea.

Boa leitura a todos! 